\title{
Adsorption of EDCs on Reclaimed Water-Irrigated Soils: A Comparative Analysis of a Branched Nonylphenol, Nonylphenol and Bisphenol A
}

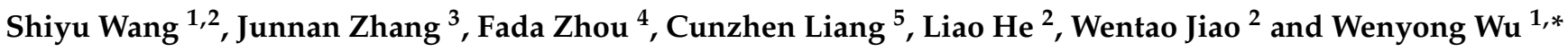 \\ 1 State Key Laboratory of Simulation and Regulation of the Water Cycle in the River Basin, China Institute of \\ Water Resources and Hydropower Research, Beijing 100048, China; sywang1@rcees.ac.cn \\ 2 State Key Laboratory of Urban and Regional Ecology, Research Center for Eco-Environmental Sciences, \\ Chinese Academy of Sciences, Beijing 100085, China; 2018520089@bipt.edu.cn (L.H.); wtjiao@rcees.ac.cn (W.J.) \\ 3 China Nuclear Power Engineering Co., Ltd., Beijing 100840, China; zhangjna@cnpe.cc \\ 4 Liaoning Sixth Geological Brigade Co., Ltd., Dalian 116200, China; 15998551852@163.com \\ 5 Department of Environmental Engineering, Beijing Institute of Petrochemical Technology, Beijing 102617, \\ China; liangcunzhen@bipt.edu.cn \\ * Correspondence: wenyongwu@126.com; Tel.: +86-13810689476
}

Citation: Wang, S.; Zhang, J.; Zhou, F.; Liang, C.; He, L.; Jiao, W.; Wu, W. Adsorption of EDCs on Reclaimed Water-Irrigated Soils: A Comparative Analysis of a Branched Nonylphenol, Nonylphenol and Bisphenol A. Water 2021, 13, 2532. https://doi.org/ $10.3390 /$ w13182532

Academic Editor: Zhengyi Hu

Received: 11 August 2021

Accepted: 3 September 2021

Published: 15 September 2021

Publisher's Note: MDPI stays neutral with regard to jurisdictional claims in published maps and institutional affiliations.

Copyright: () 2021 by the authors. Licensee MDPI, Basel, Switzerland. This article is an open access article distributed under the terms and conditions of the Creative Commons Attribution (CC BY) license (https:// creativecommons.org/licenses/by/ $4.0 /)$.

\begin{abstract}
Nonylphenol (NP) and bisphenol A (BPA) are two typical endocrine disrupter chemicals (EDCs) in reclaimed water. In this study, the adsorptions of $\mathrm{NP}$, a branched $\mathrm{NP}\left(\mathrm{NP}_{7}\right)$ and BPA on reclaimed water-irrigated soils were studied by isothermal experiments, and the different environmental factors on their adsorptions were investigated. The results showed that the adsorptions of $\mathrm{NP}$ and $\mathrm{NP}_{7}$ on soils conformed to the Linear model, and the adsorption of BPA conformed to the Freundlich model. The adsorptions of NP, $\mathrm{NP}_{7}$ and BPA on soils decreased with increasing temperatures and $\mathrm{pHs}$. Adsorption equilibrium constant $\left(\mathrm{K}_{\mathrm{d}}\right.$ or $\left.\mathrm{K}_{\mathrm{f}}\right)$ were maximum at $\mathrm{pH}=3$, temperature $25^{\circ} \mathrm{C}$ and $\mathrm{As}(\mathrm{III})$-soil, respectively. The adsorption capacity of $\mathrm{NP}, \mathrm{NP}_{7}$ and BPA to soils under different cation valence were as follows: neutrally $>$ divalent cations $>$ mono-cations. $\mathrm{K}_{\mathrm{d}}$ of $\mathrm{NP}_{7}$ on soil was less than that of NP under different $\mathrm{pH}$ and temperatures, while under different cation concentrations it was the inverse. Fourier Transform Infrared Spectrometer (FTIR) analysis showed alkyl chains of NP and BPA seemed to form van der Waals interactions with the cavity of soil. Results of this study will provide further comprehensive fundamental data for human health risk assessment of NP and BPA in soil.
\end{abstract}

Keywords: nonylphenol; isomer; bisphenol A; adsorption; mechanism; reclaimed water soil

\section{Introduction}

Irrigation with reclaimed water is a key method of alleviating agricultural water shortages (FAO, 2012) [1]. Recycled water can save water resources and promote the circulation of nutrients, but pollutants in reclaimed water and soil have potential to cause health risks to humans, especially the endocrine disrupter chemicals (EDCs), which have attracted wide attention recently. EDCs can lead to endocrine disorders in aquatic organisms, affecting reproductive development and the immune system [2,3].

Reclaimed water from wastewater treatment plants (WWTPs) is regarded as one of the main sources of EDCs in the agricultural environment. In addition to reclaimed water or effluent, treated sewage sludge is also used all over the world in agriculture soil [4-7]. Municipal landfills also contain leachate with significant amounts of EDCs that could migrate into groundwater [8-11]. In recent years, the fate of EDCs in groundwater and reclaimed water has received much attention [12-15].

Nonylphenol (NP) and bisphenol A (BPA) are two typical EDCs with high detection frequencies and concentrations in soils irrigated with reclaimed water [16,17]. The concentrations of NP in reclaimed water and agricultural soils were $0.05-63 \mu \mathrm{g} \cdot \mathrm{L}^{-1}$ and 
$14.2-60.3 \mathrm{mg} \cdot \mathrm{kg}^{-1}$, respectively $[13,18-21]$. The concentrations of BPA in reclaimed water and agricultural soil were ND-101.6 $\mu \mathrm{g} \cdot \mathrm{L}^{-1}$ and ND-147 $\mu \mathrm{g} \cdot \mathrm{kg}^{-1}$, respectively [16,22-25]. The Danish Institute of Safety and Toxicology (DIST) derived a preliminary tolerable daily intake (TDI) value for NP of $5 \mu \mathrm{g}$. (day kg) ${ }^{-1}$ body weight [26]. USEPA estimated a reference dose for BPA of $50 \mu \mathrm{g} \cdot(\text { day } \mathrm{kg})^{-1}$ body weight [27].

$\mathrm{NP}$ is composed of varieties of isomers. The estrogenic activity and the environmental fate were heavily dependent on the isomer structures, such as the side-chain length, degree of branching, $\alpha$-substituent type and steric index [28-30]. The most toxic isomer among these isomers is 4-(3-ethyl-2-methylhexan-2-yl) phenol, which is noted as $\mathrm{NP}_{7}[19,31]$ (Supplementary Material S1) in this study. Adsorption, migration, and degradation are the main processes for organic substances in soil. Degradation is the main fate of NP and BPA in soil during the reclaimed water irrigation. NP in sewage irrigation soil completed the rapid degradation stage within 20 days, and the removal rates reached above $80 \%$ [32], while adsorption is the first step for NP and BPA during the degradation process, which determines the rate of migration and transformation of NP and BPA into groundwater [33]. Adsorption of NP and BPA on soils is affected by a variety of factors, including dissolved organic matter (DOM), temperature, $\mathrm{pH}$ and ionic content [34-38], among which dissolved DOM plays a significant role [38-40].

The Daxing irrigation district, in the southeastern part of Beijing, China, was one of the typical sewage irrigation districts for more than 40 years. Previous studies of this district focused on inorganic pollution or total NP isomers [41,42]. The study of individual isomers is quite few because of the difficulty in the separation of NP isomers, while the risks of the different isomers to the local ecological environment were different. In particular, the most toxic isomer, $\mathrm{NP}_{7}$, has much estrogenic activity to the environment, so the study on adsorption and desorption of the NP isomer on field soil is imperative. The aim of this work is to investigate: (1) Comparison of the adsorption of $\mathrm{NP}, \mathrm{NP}_{7}$ and $\mathrm{BPA}$ on field soil irrigated with reclaimed water; (2) The effect of different environmental factors of $\mathrm{pH}$, temperature and different polyvalent metal ions $\left(\mathrm{Na}^{+}, \mathrm{Ca}^{2+}, \mathrm{As}(\mathrm{III})\right)$ on the adsorption of NP, $\mathrm{NP}_{7}$ and BPA; (3) The mechanism of sorption of NP and BPA on soil by Fourier Transform Infrared Spectrometer (FTIR) analysis.

\section{Materials and Methods}

\subsection{Reagents and Materials}

Soils $(0 \sim 20 \mathrm{~cm})$ were collected from Daxing reclaimed water irrigation district, China $\left(39^{\circ} 36^{\prime} \mathrm{N}, 116^{\circ} 21^{\prime} \mathrm{E}\right)$. After the plants' debris and residues were removed, the soils were freeze-dried at $-20{ }^{\circ} \mathrm{C}$ and then $0.9 \mathrm{~mm}$-sieved. The physicochemical properties of the soil are shown in Table 1 . The background concentrations of NP, $\mathrm{NP}_{7}$ and BPA in collected soils were $37 \mu \mathrm{g} \cdot \mathrm{kg}^{-1}, 2 \mu \mathrm{g} \cdot \mathrm{kg}^{-1}$ and below the method detection limit (MDL), respectively, and are reported in the former study [17].

Table 1. The physicochemical properties of the soil.

\begin{tabular}{|c|c|}
\hline Parameters & Values \\
\hline $\mathrm{pH}$ & 8.1 \\
\hline $\mathrm{OM}^{1}(\mathrm{~g} / \mathrm{kg})$ & 4.41 \\
\hline OC $(\%)$ & 0.47 \\
\hline $\operatorname{SSA}\left(\mathrm{m}^{2} / \mathrm{g}\right)$ & 4.79 \\
\hline Clay $(\%)$ & 15 \\
\hline $\mathrm{CEC}(\mathrm{cmol} / \mathrm{kg})$ & 3.09 \\
\hline $\mathrm{NO}_{3}{ }^{-}(\mathrm{mg} / \mathrm{kg})$ & 103.86 \\
\hline $\mathrm{PO}_{4}{ }^{3-}(\mathrm{mg} / \mathrm{kg})$ & 8.57 \\
\hline $\mathrm{Ca}(\mathrm{g} / \mathrm{kg})$ & 24 \\
\hline $\mathrm{Mg}(\mathrm{g} / \mathrm{kg})$ & 6.16 \\
\hline $\mathrm{Na}(\mathrm{g} / \mathrm{kg})$ & 0.143 \\
\hline
\end{tabular}

Note: CEC: cation exchange capacity; OM: organic matter (Supplementary Material S2); OC: organic carbon; SSA specific surface area. 
NP $(0.25 \mathrm{~g}, 100 \%)$ and BPA $(0.25 \mathrm{~g}, 99.8 \%)$ were purchased from Dr. Ehrenstorfer $\mathrm{GmbH}$ and dissolved in methanol with a concentration of $1000 \mathrm{mg} \cdot \mathrm{L}^{-1} \mathrm{NaN}_{3}(200 \mathrm{~g}$, 99\%). Methanol (HPLC grade) and dichloromethane (HPLC grade) were purchased from Honeywell (Morris Plains, NJ, USA). As(III) were obtained from Sigma-Aldrich (St. Louis, $\mathrm{MO}, \mathrm{USA})$. Anhydrous calcium chloride $\left(\mathrm{CaCl}_{2}\right)(500 \mathrm{~g},>96 \%)$, sodium chloride $(\mathrm{NaCl})$ $(500 \mathrm{~g},>99.5 \%)$ and anhydrous sodium sulfate $\left(\mathrm{Na}_{2} \mathrm{SO}_{4}\right)(500 \mathrm{~g},>98 \%)$ were obtained from the Tianjin Fuchen chemical reagents factory.

\subsection{Isothermal Adsorption Experiment}

The isothermal adsorption experiments were carried out under experimental conditions of $\mathrm{pH} 7$ at $25^{\circ} \mathrm{C}$. We added $0.2 \mathrm{~g}$ soil into a $40 \mathrm{~mL}$ brown vial, with $30 \mathrm{~mL} 0.01 \mathrm{M} \mathrm{CaCl}_{2}$ solution as the background electrolyte (except for the polyvalent metal ions experiment). $\mathrm{NaN}_{3}$ was added at a concentration of $200 \mathrm{mg} \mathrm{L}^{-1}$ to sterilize the soil. NP (or BPA) solution was added at an initial concentration of 200,500, 1000, 1500, 2000, 3000 and $4000 \mu \mathrm{g} \cdot \mathrm{L}^{-1}$. The brown bottles were placed in a thermostatic shaker at $25^{\circ} \mathrm{C}$. NP and BPA were allowed to adsorb on the soil for $24 \mathrm{~h}$ to reach equilibrium. After the samples were centrifuged for $5 \mathrm{~min}$ (3000 rpm), NP (or BPA) in the supernatant was extracted (Supplementary Material S3) according to USEPA 3550C [43], and determined by Gas Chromatograph Mass Spectrometer (GC-MS). The effects of different environmental factors on the adsorption were studied, including $\mathrm{pH}$ of the solution ( $\mathrm{pH} 3.7$, and 11), temperatures $\left(5^{\circ} \mathrm{C}, 25{ }^{\circ} \mathrm{C}\right.$ and $35^{\circ} \mathrm{C}$ ) and polyvalent metal ions $\left(\mathrm{Na}^{+}, \mathrm{Ca}^{2+}\right.$ and $\left.\mathrm{As}(\mathrm{III})\right)$ with a concentration of $0.002 \mathrm{M}$. For the polyvalent metal ions experiment, the background electrolytes were $\mathrm{Na}^{+}, \mathrm{Ca}^{2+}$ and As(III) solution, respectively. The experiment was conducted in triplicate.

\subsection{Dissolved Organic Matter (DOM)}

In order to verify the effect of temperature on the dissolution of DOM, soil and water were mixed at a ratio of $1: 150$, shaking for $24 \mathrm{~h}$ at 5,25 and $35^{\circ} \mathrm{C}$, respectively. Then the solution was centrifuged at $3000 \mathrm{rpm}$. DOM in the supernatant solution was measured with TOC instrument.

\subsection{Data Analysis}

The commonly used isothermal adsorption models are Linear adsorption model, Langmuir model and Freundlich model. The formulas are as follows:

2.4.1. Linear Adsorption Model

$$
\mathrm{C}_{\mathrm{s}}=\mathrm{K}_{\mathrm{d}} \times \mathrm{C}_{\mathrm{e}}
$$

$\mathrm{K}_{\mathrm{d}}$ : Adsorption equilibrium constant $\left(\mathrm{L} \cdot \mathrm{kg}^{-1}\right)$.

$\mathrm{C}_{\mathrm{e}}$ : Concentration of pollutants in the liquid phase at equilibrium $\left(\mathrm{mg} \cdot \mathrm{L}^{-1}\right)$.

$\mathrm{C}_{\mathrm{s}}$ : Concentration of pollutants in the solid phase at equilibrium $\left(\mathrm{mg}^{\mathrm{kg}} \mathrm{kg}^{-1}\right)$.

2.4.2. Langmuir Adsorption Model

$$
\frac{1}{\mathrm{C}_{\mathrm{s}}}=\frac{1}{\left(\mathrm{Q}_{\max } \times \mathrm{K}_{\mathrm{L}} \times \mathrm{C}_{\mathrm{e}}\right)}+\frac{1}{\mathrm{Q}_{\max }}
$$

$\mathrm{Q}_{\max }$ : Maximum sorption amount of pollutants on solids $\left(\mathrm{mg} \cdot \mathrm{kg}^{-1}\right)$.

$\mathrm{C}_{\mathrm{e}}$ : Concentration of pollutants in the liquid phase at equilibrium $\left(\mathrm{mg} \cdot \mathrm{L}^{-1}\right)$.

$\mathrm{C}_{\mathrm{s}}$ : Concentration of pollutants in the solid phase at equilibrium $\left(\mathrm{mg} \cdot \mathrm{kg}^{-1}\right)$.

$\mathrm{K}_{\mathrm{L}}$ : Adsorption equilibrium constant $\left(\mathrm{L} \mathrm{mg}^{-1}\right)$.

2.4.3. Freundlich Adsorption Model

$$
\mathrm{C}_{\mathrm{s}}=\mathrm{K}_{\mathrm{f}} \times \mathrm{C}_{\mathrm{e}}^{\frac{1}{\mathrm{n}}}
$$


$\mathrm{K}_{\mathrm{f}}$ : Adsorption equilibrium constant $\left(\mathrm{mg}^{1-1 / \mathrm{n}} \mathrm{L}^{1 / \mathrm{n}} / \mathrm{kg}\right)$.

$\mathrm{C}_{\mathrm{e}}$ : Concentration of pollutants in the liquid phase at equilibrium $\left(\mathrm{mg} \mathrm{L}^{-1}\right)$.

$\mathrm{C}_{\mathrm{s}}$ : Concentration of pollutants in the solid phase at equilibrium $\left(\mathrm{mg} \cdot \mathrm{kg}^{-1}\right)$.

$1 / \mathrm{n}$ : Adsorption force parameter (dimensionless).

\subsubsection{Organic Carbon Adsorption Constants}

The soil sorption constants were normalized to the organic carbon sorption constants $\left(\mathrm{K}_{\mathrm{oc}}\right)$. Because the main adsorbent is organic carbon in soil, and $\mathrm{K}_{\mathrm{oc}}$ is a characterization of the sorption capacity of organic carbon. The formula is:

$$
\mathrm{K}_{\mathrm{oc}}=\mathrm{K}_{\mathrm{d}} / \mathrm{f}
$$

$\mathrm{K}_{\mathrm{oc}}$ : Adsorption coefficient of pollutants on organic carbon $\left(\mathrm{mg} \cdot \mathrm{kg}^{-1}\right)$.

$\mathrm{K}_{\mathrm{d}}$ : Adsorption coefficient of pollutants on soil $\left(\mathrm{mg} \cdot \mathrm{kg}^{-1}\right.$ ).

f: Organic carbon content in soil (\%).

\subsubsection{Determination of NP and BPA}

NP and BPA were detected with GC-MS (Agilent, 6890 N/5975), with automatic sampler (7683B Series), capillary-column $(60 \mathrm{~m} \times 0.25 \mu \mathrm{m} \times 0.25 \mathrm{~mm}$, DB-5MS, Agilent Technologies, Palo Alto, CA, USA). The parameters were as follows: the inlet and the detector temperatures were set at $250{ }^{\circ} \mathrm{C}$ and $280{ }^{\circ} \mathrm{C}$, respectively. Helium was used as the carrier gas, and the flow rate was $1 \mathrm{~mL} \mathrm{~min}{ }^{-1}$. The injection mode was splitless, at a sample volume of $1 \mu \mathrm{L}$. The oven was heated as follows: Initial temperature was set at $40^{\circ} \mathrm{C}$ and maintained for $1 \mathrm{~min}$, heated to $150^{\circ} \mathrm{C}$ at a rate of $8^{\circ} \mathrm{C} \mathrm{min}^{-1}$ and maintained for $1 \mathrm{~min}$, and then heated to $230^{\circ} \mathrm{C}$ at a rate of $5^{\circ} \mathrm{C} \mathrm{min}^{-1}$ and maintained for $2 \mathrm{~min}$. The ion source was electron impact and the temperatures of the ion source and triple-quadrupole were $230^{\circ} \mathrm{C}$ and $150^{\circ} \mathrm{C}$, respectively; the voltage was $70 \mathrm{eV}$. Data were acquired with both Scan and SIM mode, and the scan range was 50 to $300 \mathrm{amu}$. The MDLs for NP isomers were $0.86-2.65 \mu \mathrm{g} \cdot \mathrm{kg}^{-1}$, and the MDL of BPA was $2.0 \mu \mathrm{g} \cdot \mathrm{kg}^{-1}$. The method recovery for NP and BPA ranged from $70 \%$ to $110 \%$, which met the standard of the U.S. EPA [17].

\subsubsection{FTIR Analysis}

Soil before and after adsorption by NP and BPA were characterized by FTIR-650 with a deuterated triglycine sulfate (DTGS) detector. The instrument was under continuous dry air purge to eliminate atmospheric water vapor. Interferograms were averaged for $400-4000$ scans at $4 \mathrm{~cm}^{-1}$ resolutions.

\subsubsection{Statistical Analysis}

IBM SPSS Statistics 22 software was used for the statistical analysis. The statistical differences were assessed using the one-way ANOVA test. The significance level of 0.05 and 0.001 was selected for all tests. In addition, different adsorption models and thermodynamic equations were used to fit the experimental data. The plotting and fitting of data were conducted using the Origin 9 software (OriginLab Corporation, Northampton, MA, USA).

\section{Results and Discussion}

\subsection{Isothermal Adsorption}

The adsorption of (a) NP, (b) $\mathrm{NP}_{7}$ and (c) BPA on soil is shown in Figure 1. The adsorption of NP on soil conforms to the Linear and Freundlich models with the correlation coefficient of greater than 0.97 (Table 2). The correlation coefficient of $\mathrm{NP}_{7}$ was 0.98 for the Linear model, so generally the adsorption of $\mathrm{NP}$ and $\mathrm{NP}_{7}$ on soil followed the Linear model and were similar with the previous studies. Düring et al. [44], Murillo-Torres et al. [45] and Martz et al. [46] concluded that NP followed a Linear adsorption model on agricultural soils, while Francis et al. [47] and Jiang et al. [48] concluded that the Freundlich model and Dubinin-Ashtakhov (DA) model were appropriate for the adsorption of NP on soil. The adsorption of BPA was in accordance with the Freundlich model in this 
study $\left(R^{2}=0.95\right)$. Tang et al. [49] found that the adsorption of BPA on herbal peat was in accordance with the Langmuir and Freundlich models, while the adsorptions of BPA on soils and sediments were in accordance with the Freundlich model. Some research indicated that EDCs can be attached to several components in soil, including clays, iron oxides and organic matter [50,51]. According to previous studies, hydrogen bonding and $\pi-\pi$ interactions play a more important role than hydrophobic interaction in the adsorption of EDCs [52-54]. Laboratory experiments demonstrated that EDCs were easily adsorbed by humic acid (HA) via hydrophobic interaction, hydrogen bonding and p-p electron donor-acceptor interactions [55].

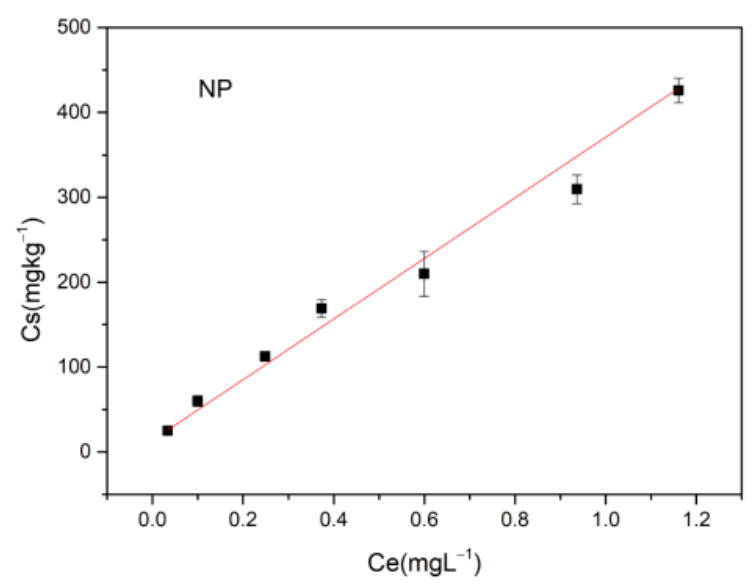

(a)

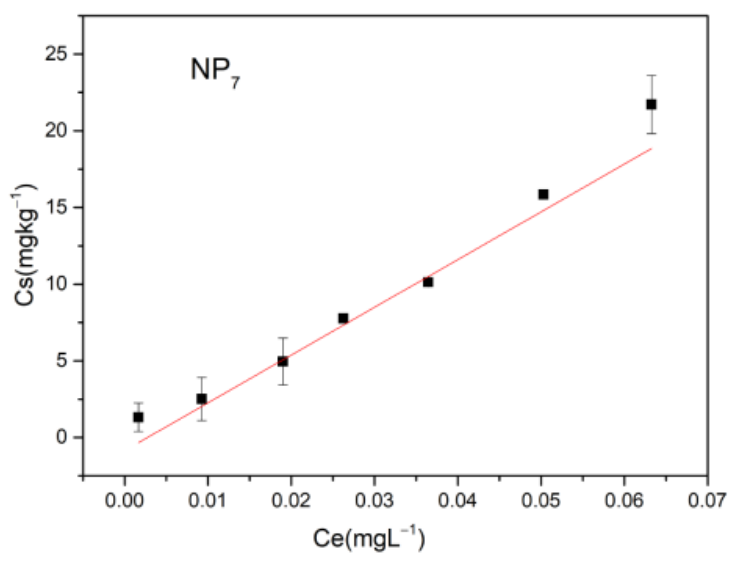

(b)

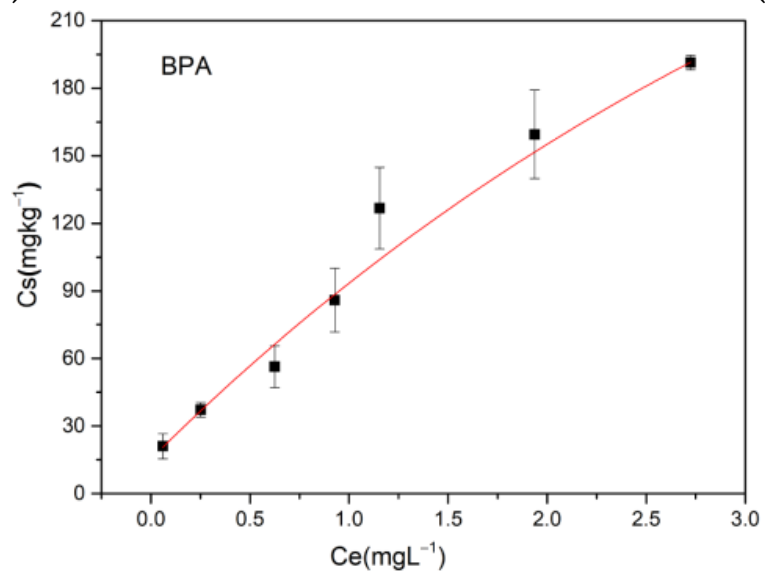

(c)

Figure 1. Adsorption of (a) $\mathrm{NP},(\mathbf{b}) \mathrm{NP}_{7}$ and (c) BPA on soil. Note: $\mathrm{C}_{\mathrm{e}}$ indicates the concentrations of pollutants in the liquid $\left(\mathrm{mg} \cdot \mathrm{L}^{-1}\right) . \mathrm{C}_{\mathrm{s}}$ indicates the concentrations of pollutants adsorbed on the soil $\left(\mathrm{mg} \cdot \mathrm{L}^{-1}\right)$.

Table 2. Adsorption models for NP, $\mathrm{NP}_{7}$ and BPA on soil.

\begin{tabular}{|c|c|c|c|c|c|c|c|c|}
\hline & \multicolumn{2}{|c|}{ Linear } & \multicolumn{3}{|c|}{ Freundlich } & \multicolumn{3}{|c|}{ Langmuir } \\
\hline & $\begin{array}{c}\mathrm{K}_{\mathrm{d}} \\
\left(\mathrm{mg} \cdot \mathrm{kg}^{-1}\right)\end{array}$ & $\mathbf{R}^{2}$ & $\underset{\left(\mathrm{mg}^{1-1 / \mathrm{n}} \cdot \mathrm{L}^{1 / \mathrm{n}} / \mathrm{kg}\right)}{K_{\mathrm{f}}}$ & $1 / n$ & $\mathbf{R}^{2}$ & $\underset{\left(\mathrm{L} \cdot \mathrm{mg}^{-1}\right)}{\mathrm{K}_{\mathrm{L}}}$ & $\begin{array}{c}\mathrm{Q}_{\max } \\
\left(\mathrm{mg} \cdot \mathrm{kg}^{-1}\right)\end{array}$ & $\mathbf{R}^{2}$ \\
\hline $\mathrm{NP}$ & 360.42 & 0.97 & 342.41 & 0.77 & 0.99 & - & - & - \\
\hline $\mathrm{NP}_{7}$ & 318.30 & 0.98 & 137.00 & 0.77 & 0.93 & - & - & - \\
\hline BPA & 81.65 & 0.81 & 103.28 & 0.61 & 0.95 & 4 & 125 & 0.90 \\
\hline
\end{tabular}


The $\mathrm{K}_{\mathrm{oc}}$ of NP in irrigated soil was $7.56 \times 10^{4} \mathrm{~L} \cdot \mathrm{kg}^{-1}$ in this study (Table 3), which was similar to the study on other agricultural soils with a similar magnitude of $10^{3}-10^{4}[56,57]$. Likewise, the $\mathrm{K}_{\mathrm{OC}}$ of NP adsorbed in the sediments and suspended particles has an equal magnitude to that in this study, which was $10^{4}-10^{5} \mathrm{~L} \cdot \mathrm{kg}^{-1}[39,58-60]$. The adsorption of NP on soil is not only related to the organic matter [39], but also depends on the structures of the isomers. $\mathrm{NP}_{7}$, the most toxic isomer, the $\mathrm{K}_{\mathrm{oc}}$ of which was $6.67 \times 10^{4} \mathrm{~L}^{\mathrm{kg}} \mathrm{kg}^{-1}$, was $11.77 \%$ lower than that of NP. The adsorption of NP isomers has also been studied previously. Düring et al. [44] found that the $\mathrm{K}_{\mathrm{oc}}$ of $4-\mathrm{n}-\mathrm{NP}$ was $7.9 \times 10^{4} \mathrm{~L} \cdot \mathrm{kg}^{-1}$ on soils, which was eight times higher than that of other branched NP. The $\mathrm{K}_{\mathrm{oc}}$ of 4-n-NP in sediments from the Ebro River was $4.0 \times 10^{3}-4.9 \times 10^{4} \mathrm{~L}^{\mathrm{kg}} \mathrm{kg}^{-1}$ [60]. Li et al. [61] reported that the $\mathrm{K}_{\mathrm{oc}}$ of NP111 (4-(1-ethyl-1,3-dimethylpentyl) phenol) on seven sediments was $6.1 \times 10^{3}-1.1 \times 10^{4} \mathrm{~L} \cdot \mathrm{kg}^{-1}$, which was a little smaller than the $\mathrm{K}_{\mathrm{oc}}$ of $\mathrm{NP}_{7}$ on the soil in this study. This was because the seven sediments contained more than $40 \%$ illite and were not prone for adsorption of NP. Ding et al. [39] found the $\log \mathrm{K}_{\mathrm{oc}}$ value was 4.98 in Chaozhou Lake sediments, suggesting a strong adsorption effect of DOM.

Table 3. $\mathrm{K}_{\mathrm{oc}}$ of $\mathrm{NP}$ and $\mathrm{NP}_{7}$ on soil.

\begin{tabular}{ccc}
\hline Organic Carbon Sorption Constant & $\mathbf{N P}$ & $\mathbf{N P}_{\mathbf{7}}$ \\
\hline $\mathrm{K}_{\mathrm{oc}}\left(\mathrm{L} \cdot \mathrm{kg}^{-1}\right)$ & $7.56 \times 10^{4}$ & $6.67 \times 10^{4}$ \\
\hline
\end{tabular}

\subsection{Environmental Factors of Adsorption}

\subsection{1. $\mathrm{pH}$}

As shown in Figure 2, the partition coefficients $\mathrm{K}_{d}$ of NP and $\mathrm{NP}_{7}$ at $\mathrm{pH} 3$ have the highest values of $374.36 \mathrm{~L} \cdot \mathrm{kg}^{-1}$ and $328.42 \mathrm{~L} \cdot \mathrm{kg}^{-1}$, respectively. $\mathrm{K}_{\mathrm{f}}$ was $157.76 \mathrm{mg}^{1-1 / \mathrm{n}} \cdot \mathrm{L}^{1 / \mathrm{n}} / \mathrm{kg}$ for BPA (Table 4). The adsorption of NP and BPA on soils decreased with increasing $\mathrm{pH}$. At $\mathrm{pH} 7$, the $\mathrm{K}_{\mathrm{d}}$ of $\mathrm{NP}$ and $\mathrm{NP}_{7}$ decreased by $3.7 \%$ and $3.0 \%$ when compared with $\mathrm{pH} 3$. The $\mathrm{K}_{\mathrm{d}}$ of $\mathrm{NP}$ and $\mathrm{NP}_{7}$ decreased by $58.1 \%$ and $31.9 \%$, respectively, at $\mathrm{pH} 11$ compared with $\mathrm{pH} 3$, of which the decrease was greater. Likewise, the adsorption of BPA decreased with $\mathrm{pH}$ as well. At $\mathrm{pH} 7$ and $\mathrm{pH} 11$, the $\mathrm{K}_{\mathrm{f}}$ of BPA on soil was $34.5 \%$ and $36.9 \%$ lower than that at $\mathrm{pH} 3$ (Table 4). This trend was consistent with previous results [34,37]. The reason for this change was that NP and BPA were deprotonated when the solution $\mathrm{pH}$ reached their dissociation constants ( $\mathrm{pka}$ ), which enhanced the electrostatic interactions between the pollutants and soils by converting molecules into ions when the solution $\mathrm{pH}$ reached their pka. As the soil surface was negatively charged, the electrostatic repulsion between EDCs and soil increased with the alkaline conditions of solution, resulting in a decrease in adsorption capacity [49]. Many other factors are likely to be important as well as the electrostatic repulsion, including hydrogen bonding, surface complexion and cation exchange. In addition, the partitioning behavior of the ionizable EDCs is highly susceptible to change the soil $\mathrm{pH}$ and therefore may alter the ionic fraction. An empirical relationship exists between a chemical's lipophilicity and its affinity to adsorption on soil organic matter [62].

Table 4. Freundlich model for BPA on soil at different $\mathrm{pHs}$.

\begin{tabular}{ccccc}
\hline $\mathbf{p H}$ & $\mathbf{K}_{\mathbf{f}}\left(\mathbf{m g}^{\mathbf{1 - 1 / \mathbf { n }}} \cdot \mathbf{L}^{\mathbf{1 / n}} \mathbf{/ k g}\right)$ & $\mathbf{1 / n}$ & $\mathbf{R}^{\mathbf{2}}$ & $p$ Value \\
\hline 3 & 157.76 & 0.49 & 0.96 & $<0.001$ \\
7 & 103.28 & 0.613 & 0.95 & $<0.001$ \\
\hline
\end{tabular}




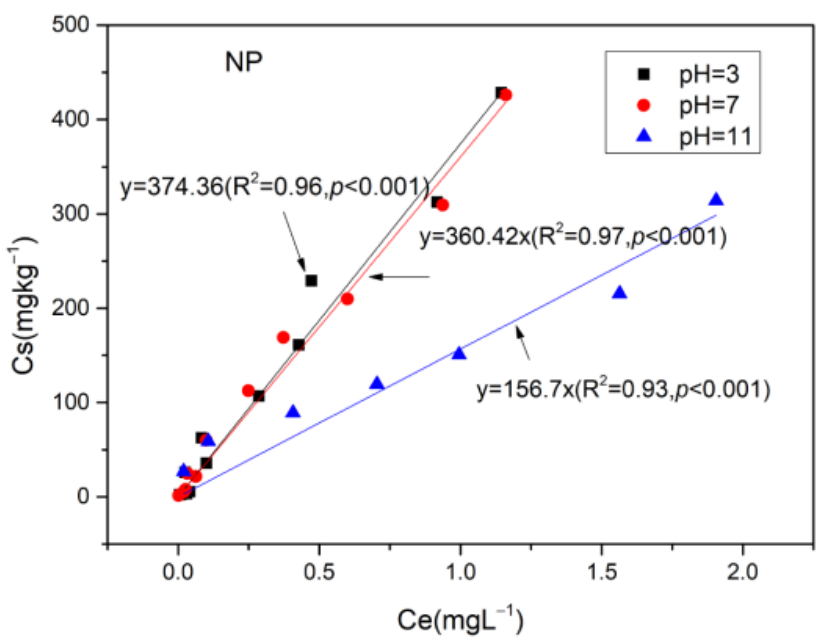

(a)

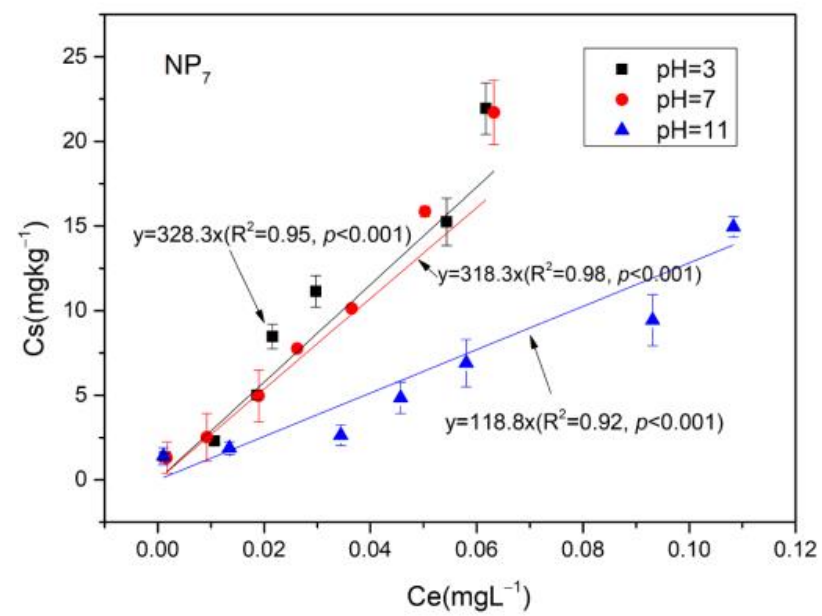

(b)

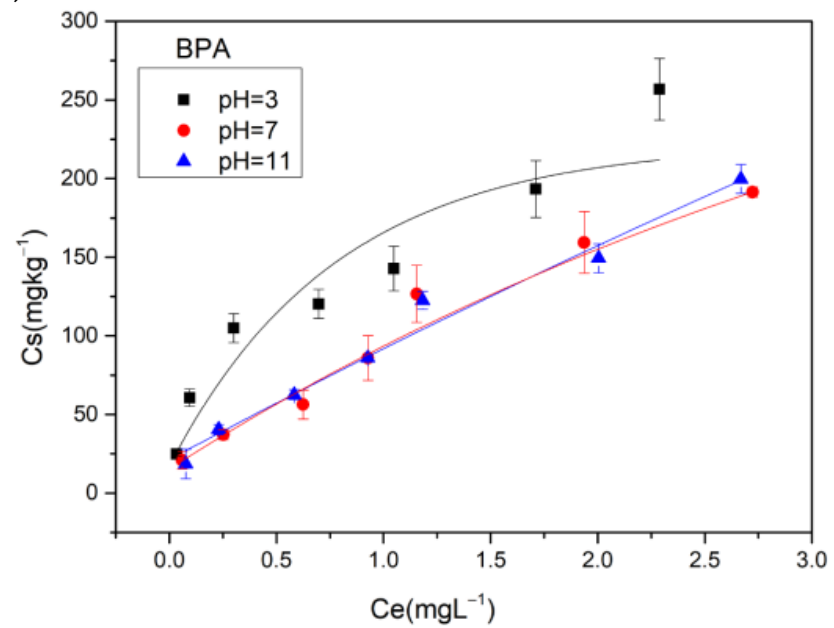

(c)

Figure 2. Adsorption of (a) $\mathrm{NP},(\mathbf{b}) \mathrm{NP}_{7}$ and (c) BPA on soil at different pHs.

\subsubsection{Temperature}

As shown in Figure $3, \mathrm{~K}_{\mathrm{d}}$ for NP on the soil was $488.5 \mathrm{~L} \cdot \mathrm{kg}^{-1}$ at $5{ }^{\circ} \mathrm{C}$. At $25{ }^{\circ} \mathrm{C}$ and $35{ }^{\circ} \mathrm{C}$, it decreased by $26.2 \%$ and $28.5 \%$, respectively. For $\mathrm{NP}_{7}$, at $5{ }^{\circ} \mathrm{C}, \mathrm{K}_{\mathrm{d}}$ in soil was $369.7 \mathrm{~L} \cdot \mathrm{kg}^{-1}$. When the temperatures were $25^{\circ} \mathrm{C}$ and $35^{\circ} \mathrm{C}, \mathrm{K}_{\mathrm{d}}$ decreased by $13.9 \%$ and $19.2 \%$, respectively. The effect of temperature on $\mathrm{NP}_{7}$ was less than that of NP. The adsorption capacity of NP was $34.6 \%, 13.2 \%$ and $16.9 \%$ higher than that of $\mathrm{NP}_{7}$ at $5{ }^{\circ} \mathrm{C}$, $25^{\circ} \mathrm{C}$ and $35{ }^{\circ} \mathrm{C}$, respectively. Thus, the adsorption capacity of $\mathrm{NP}_{7}$ on soil was lower than other isomers. Statistical analysis of the effect of temperature on the adsorption of NP and NP7 was conducted (Supplementary Material S4). The difference of the temperature effect on the adsorption of NP7 and NP at $5{ }^{\circ} \mathrm{C}$ was not significant $(p>0.05)$, while the difference of the temperature effect at $25^{\circ} \mathrm{C}$ and $35^{\circ} \mathrm{C}$ was significant $(p<0.05)$. What's more, the difference was more significant at $35^{\circ} \mathrm{C}$ than $25^{\circ} \mathrm{C}$. It indicated that with the temperature increasing, the difference between the effect of temperature on NP7 and NP was more significant.

At $5^{\circ} \mathrm{C}$, the $\mathrm{K}_{\mathrm{f}}$ for BPA was $120.2 \mathrm{mg}^{1-1 / \mathrm{n}} \cdot \mathrm{L}^{1 / \mathrm{n}} / \mathrm{kg}$. The adsorption capacity of BPA decreased by $14.1 \%$ and $47.1 \%$ at $25^{\circ} \mathrm{C}$ and $35^{\circ} \mathrm{C}$, respectively (Table 5). It can be seen that the adsorption of $\mathrm{NP} \mathrm{NP}_{7}$, and $\mathrm{BPA}$ on the soil all decreased with increasing temperature, which was similar with the results of previous studies $[37,38]$. 

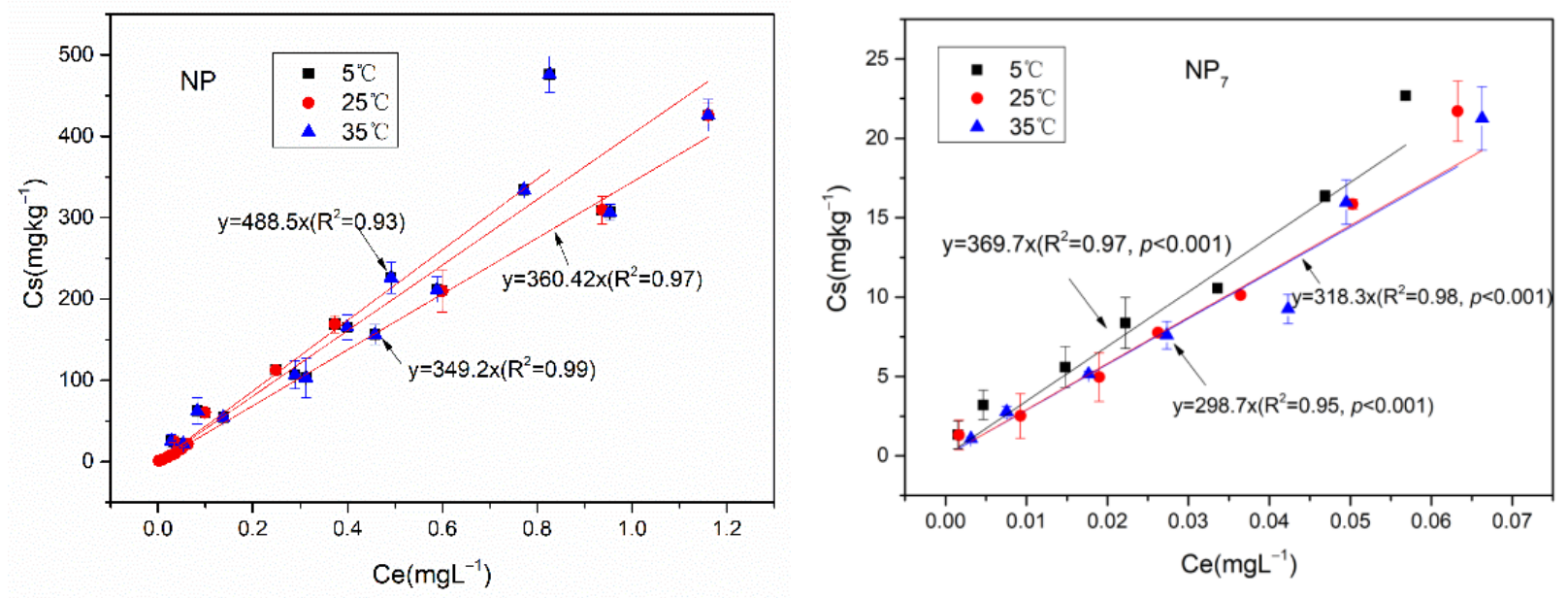

(a)

(b)

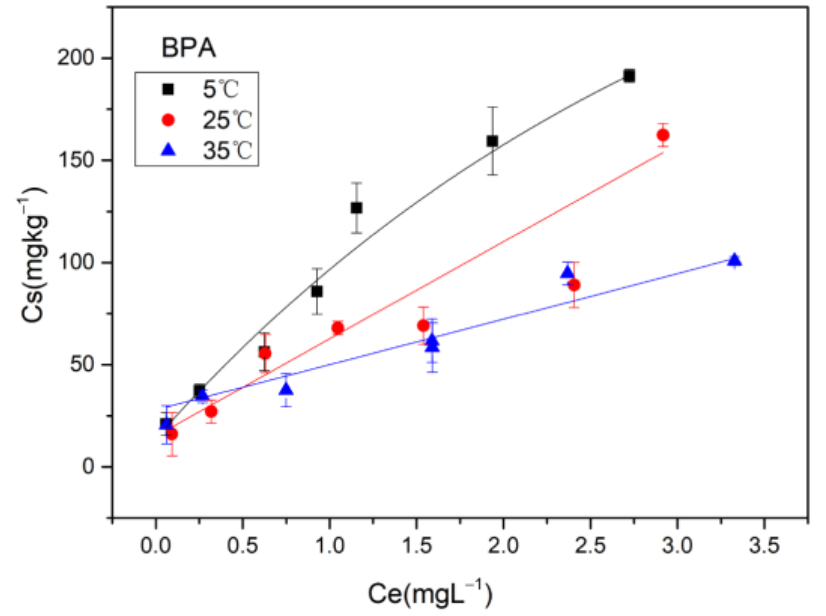

(c)

Figure 3. Adsorption of (a) NP, (b) $\mathrm{NP}_{7}$ and (c) BPA on soil at different temperatures.

Table 5. Freundlich model for BPA on soil at different temperatures.

\begin{tabular}{|c|c|c|c|c|}
\hline Temperature $\left({ }^{\circ} \mathrm{C}\right)$ & $K_{f}\left(m^{1-1 / n} \cdot L^{1 / n} / \mathbf{k g}\right)$ & $1 / n$ & $\mathbf{R}^{2}$ & $p$ Value \\
\hline 5 & 120.20 & 0.57 & 0.93 & $<0.001$ \\
\hline 25 & 103.28 & 0.613 & 0.95 & $<0.001$ \\
\hline 35 & 63.53 & 0.61 & 0.94 & $<0.001$ \\
\hline
\end{tabular}

It can be seen from Figure 4 that the DOM dissolved from soil at $35{ }^{\circ} \mathrm{C}$ was $35.59 \%$ and $20.69 \%$ higher than that at $5{ }^{\circ} \mathrm{C}$ and $25{ }^{\circ} \mathrm{C}$, indicating that increasing the temperature led to the increase of the organic matter dissolved into the aqueous phase. Sadmani et al. $[63,64]$ found that under certain disturbances, DOM can diffuse from soil pore water into water columns since DOM displays a high capacity of BPA and NP binding with its natural ligands and adsorption sites. Therefore, the decrease of DOM in soil would lead to the decrease of adsorption of EDCs. On the other hand, DOM can be adsorbed on the soil particles again, causing a redistribution of EDCs in aquatic systems [63,65]. Meanwhile, with increasing temperature, the solubility of NP and BPA in water increased and the hydrophobicity weakened, which was also the reason that the adsorptions of NP and BPA decreased with the increasing temperature. 


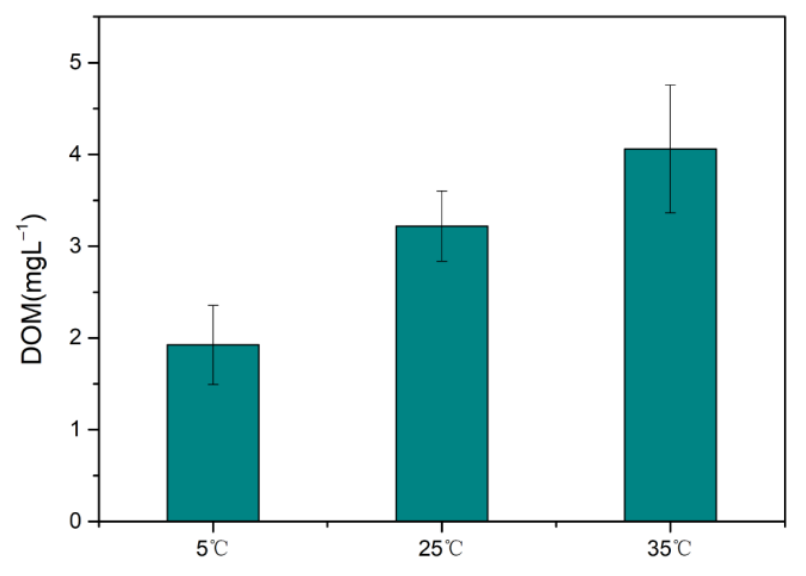

Figure 4. DOM in soil at different temperatures.

\subsubsection{Effects of Different Polyvalent Metal Ions}

The $\mathrm{K}_{\mathrm{d}}$ of NP was $387.8 \mathrm{~L} \cdot \mathrm{kg}^{-1}, 575.60 \mathrm{~L} \cdot \mathrm{kg}^{-1}$ and $607.9 \mathrm{~L} \cdot \mathrm{kg}^{-1}$, while the $\mathrm{K}_{\mathrm{d}}$ of $\mathrm{NP}_{7}$ was 341.7, 629.2 and $741.7 \mathrm{~L} \cdot \mathrm{kg}^{-1}$ with a concentration of $0.002 \mathrm{M}$ for $\mathrm{Na}^{+}, \mathrm{Ca}^{2+}$ and $\mathrm{As}(\mathrm{III})$, respectively (Figure 5). Similarly, $\mathrm{K}_{\mathrm{f}}$ of BPA in As(III)-soil system, which was $32.25 \mathrm{mg}^{1-1 / \mathrm{n}} \cdot \mathrm{L}^{1 / \mathrm{n}} / \mathrm{kg}$, was greater compared with $\mathrm{Ca}^{2+}$-soil system and $\mathrm{Na}^{+}$-soil system (Table 6). The adsorption of NP on soil varied with the different cation valence. $\mathrm{NP}_{7}$ followed the same trend. $\mathrm{K}_{\mathrm{d}}$ of $\mathrm{NP}_{7}$ was $8.52 \%$ and $18.04 \%$ higher than that of $\mathrm{NP}$ for $\mathrm{Ca}^{2+}$-soil and As(III)-soil system, respectively, while in the soil- $\mathrm{Na}^{+}$system, it was the inverse.

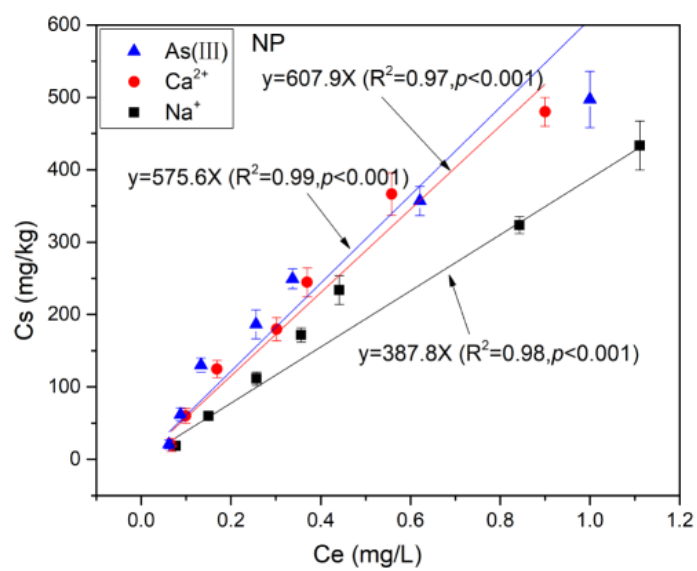

(a)

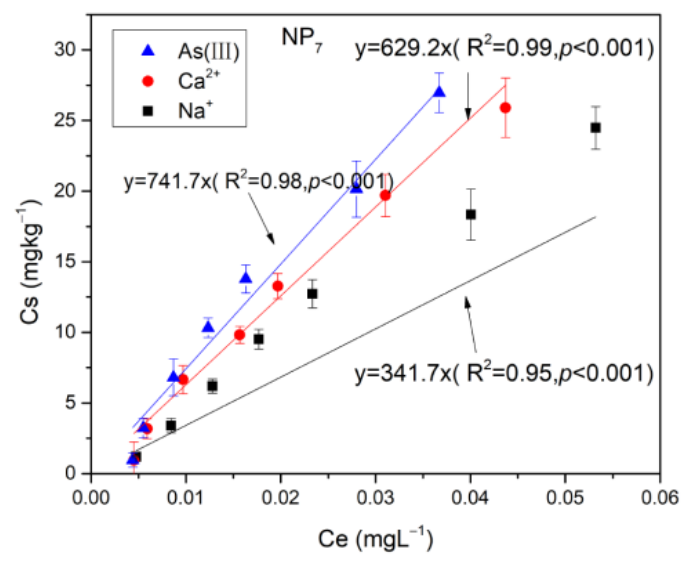

(b)

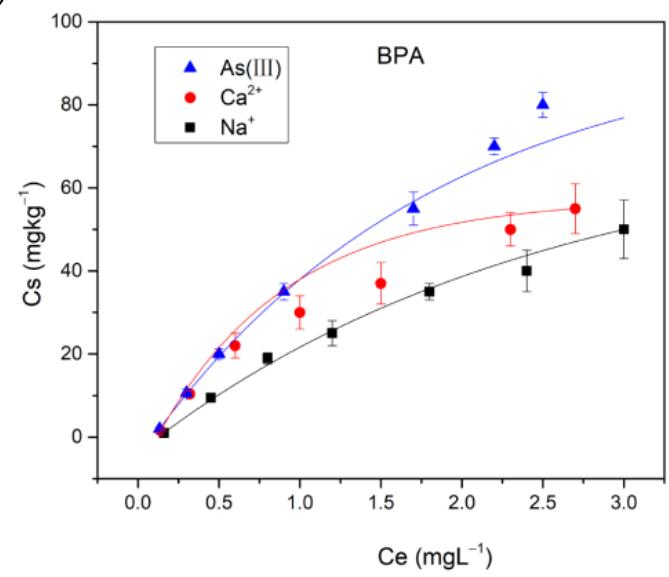

(c)

Figure 5. Adsorption of (a) NP, (b) $\mathrm{NP}_{7}$ and (c) BPA on soil saturated with different polyvalent metal ions. 
Table 6. Freundlich model for BPA on soil at different polyvalent metal ions conditions.

\begin{tabular}{|c|c|c|c|c|}
\hline Metal Ions & $K_{f}\left(m^{1-1 / n} \cdot L^{1 / n} / k g\right)$ & $1 / n$ & $\mathbf{R}^{2}$ & $p$ Value \\
\hline $\mathrm{Na}^{+}$ & 16.69 & 1.26 & 0.93 & $<0.001$ \\
\hline $\mathrm{Ca}^{2+}$ & 24.25 & 1.10 & 0.91 & $<0.001$ \\
\hline As(III) & 32.25 & 1.16 & 0.95 & $<0.001$ \\
\hline
\end{tabular}

The As(III) is neutrally charged at most soil $\mathrm{pH}$. The adsorption capacity of $\mathrm{NP}, \mathrm{NP}_{7}$ and BPA to soils varied with different cation valence: neutrally $>$ divalent cation $>$ monocation, which was similar with the study of Shchegolikhina et al. [66]. There are other studies about the effects of different polyvalent metal ions to different pollutants. Lu et al. [67] reported that divalent cations such as $\mathrm{Ca}^{2+}$ and $\mathrm{Mg}^{2+}$ were about 28 times more effective with respect to polyacrylamide adsorption than monovalent cations such as $\mathrm{Na}^{+}$ and $\mathrm{K}^{+}$, which was similar with this study. That was due to the stronger flocculation power and, consequently, to a higher charge screening ability of polyvalent cations, which increased the ability of soil particles to adsorb contaminants [36]. Experiments with HA saturated with $\mathrm{Ca}^{2+}$ or $\mathrm{Al}^{3+}$ revealed that the type of cation can significantly influence the adsorption of organic pollutants. This trend is in accordance with the increase of cation valence. $\mathrm{Al}^{3+}, \mathrm{Fe}^{3+}, \mathrm{Ca}^{2+}$ and $\mathrm{Mg}^{2+}$ can be coordinated to multiple functional groups of organic matter in soil [68] and form cation bridges or water-cation complexes [69]. This may decrease the flexibility of the soil organic matter (SOM) matrix and hence raise the diffusional resistance of partitioned molecules $[36,70]$. Alteration of SOM by formation or breaking of these cross-linking bridges may provide more sorption sites in soil, leading to an increasing adsorption ability [71].

\subsection{FTIR Spectra Analysis}

Soils and soils adsorpted with NP and BPA were characterized by FTIR-650 shown in Figure 6. The infrared spectroscopy (IR) was normalized with respect to the $\mathrm{C}=\mathrm{O}$ stretching at the band of $1000-1260 \mathrm{~cm}^{-1}$. The area of adsorptions arising from a particular species is directly proportional to the concentration of that species. Thus, in principle, it was possible to determine the concentration of multiple analytes from a single spectrum [72]. Shifts in peak positions, changes in bandwidths, intensities and band area values of the infrared bands were used to obtain valuable structural and functional information about interactions between the matters $[73,74]$.

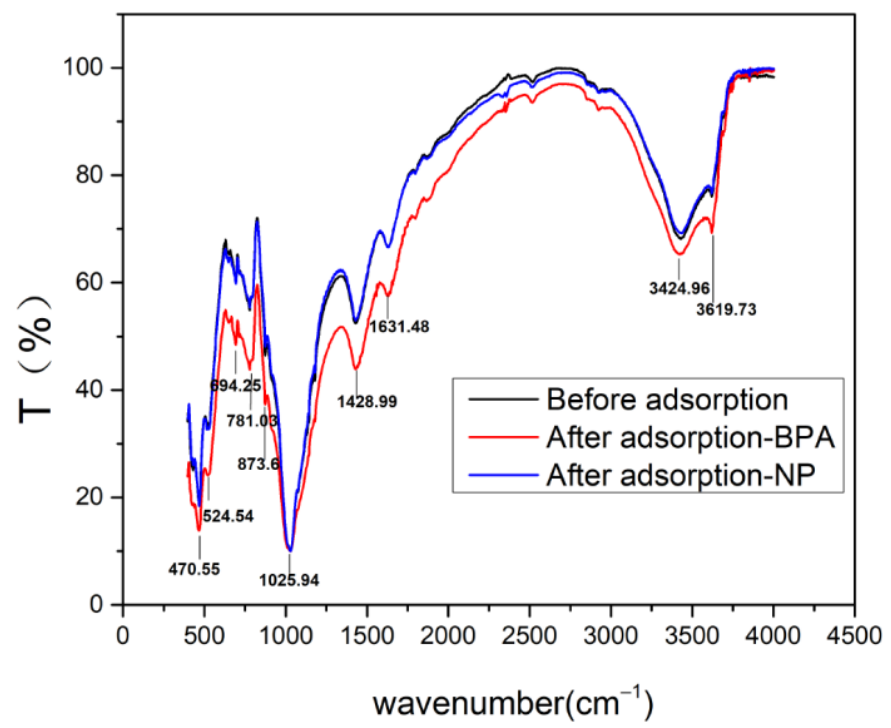

Figure 6. FTIR spectra of adsorption of NP and BPA on soil. 
There were no big differences of spectrums for soil and soil after NP adsorption. However, differences between soil and soil after BPA adsorption were significant. It was obvious that $\mathrm{T}$ of the peaks after BPA adsorption were much smaller than soil before adsorption. Bands at 693,777 and $873 \mathrm{~cm}^{-1}$ regions were by phenyl and phenol groups, such as phenyl C-P or C-H bending vibration. Bands at $1428 \mathrm{~cm}^{-1}$ were caused by scissor bending vibration, and bands at about $1620-1640 \mathrm{~cm}^{-1}$ were caused by the stretching vibration of $\mathrm{C}=\mathrm{O}$ incorporated in amide groups of proteins or $\mathrm{C}=\mathrm{C}$ stretching vibration in aromatic ring alkenes. Bands at about 3400 and $3600 \mathrm{~cm}^{-1}$ were $\mathrm{O}-\mathrm{H}$ in phenol, ethanol (etc.)s and/or amide and amine $\mathrm{N}-\mathrm{H}$. There were no shifts in peak positions, but changes occurred in intensities of band. This result meant that alkyl chains of NP and BPA seemed to form van der Waals interactions with the cavity of soil [75].

\section{Conclusions}

This study, based on laboratory batch experiments, was successful in studying the thermodynamics of adsorption of $\mathrm{NP}$ and $\mathrm{NP}_{7}$ on reclaimed water-irrigated soils. The results indicated that the adsorptions of $\mathrm{NP}$ and $\mathrm{NP}_{7}$ on soil were in accordance with the Linear model, and the adsorption of BPA on soil was in accordance with the Freundlich model. The adsorptions of $\mathrm{NP}, \mathrm{NP}_{7}$ and $\mathrm{BPA}$ on soils decreased with the increasing temperatures and $\mathrm{pH}$. The adsorption capacity of $\mathrm{NP}, \mathrm{NP}_{7}$ and BPA to soils was different with different cation valence: neutrally $>$ divalent cations $>$ mono- cations. The adsorption of $\mathrm{NP}_{7}$ on soil was quite different from the total NP, which was a further study of the previous study focusing on the total NP. Alkyl chains of NP and BPA seemed to form van der Waals interactions with the cavity of soil. But reclaimed water-irrigated soils are quite complex, and the mechanism of the differences between the total NP and individual isomer need further study. This study makes the risk assessment of NP isomers more targeted. In the future, researchers can assess the NP risks, not from the points of total NP but focusing on the isomer, which has higher estrogen activity. This study provided indispensable foundations for the human health risks of EDCs in the future.

Supplementary Materials: The following are available online at https: / www.mdpi.com/article / 10.3390/w13182532/s1, S1: Separation of NP isomers; S2: Detection of dissolved organic matter (DOM); S3: The extraction of NP and BPA; S4: Statistical analysis of the effect of temperature on the adsorption of $\mathrm{NP}$ and $\mathrm{NP}_{7}$.

Author Contributions: Experiment, methodology, formal analysis, investigation, writing, original draft, S.W.; writing — review and editing, methodology, grammar check, J.Z.; investigation, methodology, F.Z.; writing—review and editing, C.L. and L.H.; writing—review and editing, supervision, W.J.; resources, writing-review and editing, funding acquisition, project administration, supervision, W.W. All authors have read and agreed to the published version of the manuscript.

Funding: This study was funded by NSFC (Grant No. 52079146; 42107388; 41877134); China Postdoctoral Science Foundation Funded Project "The metabolism mechanism of nonylphenol and bisphenol A in winter wheat" (Grant No. 2019M660822).

Institutional Review Board Statement: Not applicable.

Informed Consent Statement: Not applicable.

Data Availability Statement: The data associated in this publication are totally presented in this paper. No data are present in any other repository anywhere.

Conflicts of Interest: The authors declare no conflict of interest.

\section{References}

1. FAO. FAO Water Reports 38, Coping with Water Scarcity: An Action Framework for Agriculture and Food Security; FAO: Rome, Italy, 2012.

2. Lee, D.W.; Oh, W.-Y.; Yi, S.H.; Ku, B.; Lee, M.-Y.; Cho, Y.H.; Yang, M. Estimation of bisphenol A human toxicity by $3 d$ cell culture arrays, high throughput alternatives to animal tests. Toxicol. Lett. 2016, 259, 87-94. [CrossRef] 
3. Tabassum, H.; Ashafaq, M.; Parvez, S.; Raisuddin, S. Role of melatonin in mitigating nonylphenol-induced toxicity in frontal cortex and hippocampus of rat brain. Neurochem. Int. 2017, 104, 11-26. [CrossRef] [PubMed]

4. Hamid, H.; Eskicioglu, C. Fate of estrogenic hormones in wastewater and sludge treatment: A review of properties and analytical detection techniques in sludge matrix. Water Res. 2012, 46, 5813-5833. [CrossRef]

5. Ömeroğlua, S.; Murdochb, F.K.; Sanina, F.D. Investigation of nonylphenol and nonylphenolethoxylates in sewage sludge samples from a metropolitan wastewater treatment plant in Turkey. Talanta 2015, 131, 650-655. [CrossRef] [PubMed]

6. Belhaj, D.; Athmouni, K.; Jerbi, B.; Kallel, M.; Ayadi, H.; Zhou, J.L. Estrogenic compounds in Tunisian urban sewage treatment plant: Occurrence, removal and ecotoxicological impact of sewage discharge and sludge disposal. Ecotoxicology 2016, 25, 1849-1857. [CrossRef] [PubMed]

7. Biel-Maeso, M.; Corada-Fernández, C.; Lara-Martin, P.A. Removal of personal care products (PCPs) in wastewater and sludge treatment and their occurrence in receiving soils. Water Res. 2019, 150, 129-139. [CrossRef]

8. Kalmykova, Y.; Björklund, K.; Strömvall, A.M.; Blom, L. Partitioning of polycyclic aromatic hydrocarbons, alkylphenols, bisphenol A and phthalates in landfill leachates and stormwater. Water Res. 2013, 47, 1317-1328. [CrossRef]

9. Zhang, F.; Xie, Y.; Li, X.; Wang, D.; Yang, L.; Nie, Z. Accumulation of steroid hormones in soil and its adjacent aquatic environment from a typical intensive vegetable cultivation of North China. Sci. Total Environ. 2015, 538, 423-430. [CrossRef]

10. Lu, J.; Wu, J.; Stoffella, P.J.; Wilson, P.C. Uptake and distribution of bisphenol A and nonylphenol in vegetable crops irrigated with reclaimed water. J. Hazard. Mater. 2015, 283, 865-870. [CrossRef]

11. Wang, S.Y.; Li, X.O.; Wu, W.Y.; Liu, F. Sorption and Desorption Behavior of 4-Nonylphenol and a Branched Isomer on Soils with Long-Term Reclaimed Water Irrigation. Environ. Eng. Sci. 2019, 36, 1100-1111. [CrossRef]

12. Goeppert, N.; Dror, I.; Berkowitz, B. Fate and transport of free and conjugated estrogens during soil passage. Environ. Pollut. 2015, 206, 80-87. [CrossRef] [PubMed]

13. Sidhu, H.S.; Wilson, P.C.; O'Connor, G.A. Endocrine-disrupting compounds in reclaimed water and residential ponds and exposure potential for dislodgable residues in turf irrigated with reclaimed water. Arch. Environ. Contam. Toxicol. 2015, 69, 81-88. [CrossRef] [PubMed]

14. Adeel, M.; Song, X.M.; Wang, Y.Y.; Francis, D.; Yang, Y.S. Environmental impact of estrogens on human, animal and plant life: A critical review. Environ. Int. 2017, 99, 107-119. [CrossRef] [PubMed]

15. Adeel, M.; Yang, Y.S.; Wang, Y.Y.; Song, X.M.; Arslan Ahmad, M.; Rogers, H.J. Uptake and transformation of steroid estrogens as emerging contaminants influence plant development. Environ. Pollut. 2018, 243, 1487-1497. [CrossRef]

16. Careghini, A.; Mastorgio, A.F.; Saponaro, S.; Sezenna, E. Bisphenol A, nonylphenols, benzophenones, and benzotriazoles in soils, groundwater, surface water, sediments, and food: A review. Environ. Sci. Pollut. Res. 2015, 22, 5711-5741. [CrossRef]

17. Wang, S.Y.; Liu, F.; Wu, W.Y.; Hu, Y.Q.; Liao, R.K.; Chen, G.T.; Wang, J.L.; Li, J.L. Migration and health risks of nonylphenol and bisphenol A in soil-winter wheat systems with long-term reclaimed water irrigation. Ecotoxicol. Environ. Saf. 2018, 158, 28-36. [CrossRef]

18. Liao, X.P.; Zhang, C.X.; Yao, L.L.; Li, J.L.; Liu, M.; Xu, L.; Evalde, M. Sorption behavior of nonylphenol (NP) on sewage-irrigated soil: Kinetic and thermodynamic studies. Sci. Total Environ. 2014, 473-474, 530-536. [CrossRef]

19. Wang, S.Y.; Wu, W.Y.; Liu, F.; Yin, S.Y.; Bao, Z.; Liu, H.L. Spatial distribution and migration of nonylphenol in groundwater following long-term wastewater irrigation. J. Contam. Hydrol. 2015, 177-178, 85-92. [CrossRef] [PubMed]

20. Kwak, J., II; Moon, J.; Kim, D.; Cui, R.X.; An, Y.J. Species Sensitivity Distributions for Nonylphenol to Estimate Soil Hazardous Concentration. Environ. Sci. Technol. 2017, 51, 13957-13966. [CrossRef]

21. Bruin, W.d.; Kritzingerbc, Q.; Bornmanc, R.; Korsten, L. Ocurrence, fate and toxic effects of the industrial endocrine disrupter, nonylphenol, on plants-A review. Ecotoxicol. Environ. Saf. 2019, 181, 419-427. [CrossRef] [PubMed]

22. Gibson, R.; Durán-Álvarez, J.C.; Estrada, K.L.; Chávez, A.; Cisneros, B.J. Accumulation and leaching potential of some pharmaceutical and potential endocrine disruptors in soils irrigated with wastewater in the Tula Valley, Mexico. Chemosphere 2010, 81, 1437-1445. [CrossRef]

23. USEPA. Bisphenol A Action Plan; U.S. Environmental Protection Agency: Washington, DC, USA, 2010.

24. Luo, Y.; Guo, W.; Ngo, H.H.; Nghiem, L.D.; Hai, F.I.; Zhang, J.; Liang, S.; Wang, X.C. A review on the occurrence of micropollutants in the aquatic environment and their fate and removal during wastewater treatment. Sci. Total Environ. 2014, 473-474, 619-641. [CrossRef]

25. Yacoumas, A.; Honvault, N.; Houben, D.; Fontaine, J.; Meglouli, H.; Laruelle, F.; Tisserant, B.; Faucon, M.-P.; Sahraoui, A.L.H.; Firmin, S. Contrasting Response of Nutrient Acquisition Traits in Wheat Grown on Bisphenol A-Contaminated Soils. Water Air Soil Pollut. 2020, 23, 1-3. [CrossRef]

26. Danish EPA. Toxicological Evaluation and Limit Values for Nonylphenol, Nonylphenol Ethoxylates, Tricresyl, Phosphates and Benzoic Acid—Environmental Project no. 512. 2000. Available online: http:/ / www.statensnet.dk/pligtarkiv/fremvis.pl? vaerkid=6944\&reprid=0\&filid=0\&iarkiv=1 (accessed on 15 December 2014).

27. USEPA-IRIS Bisphenol, A. Quickview. Available online: http://cfpub.epa.gov/ncea/iris/index.cfm?fuseaction=iris. showQuickview\&substance_nmbr=0356 (accessed on 15 November 2014).

28. Gabriel, F.L.P.; Routledge, E.J.; Heidlberger, A.; Rentsch, D.; Guenther, K.; Giger, W.; Sumpter, J.P.; Kohler, H.-P.E. Isomer specific degradation and endocrine disrupting activity of nonylphenols. Environ. Sci. Technol. 2008, 42, 6399-6408. [CrossRef] 
29. Lu, Z.J.; Gan, J. Isomer-specific biodegradation of nonylphenol in river sediments and structure-biodegradability relationship. Environ. Sci. Technol. 2014, 48, 1008-1014. [CrossRef] [PubMed]

30. Schick, D.; Oellig, C. Screening for estrogen active nonylphenols in surface waters by planar solid phase extraction-planar yeast estrogen screen. Anal. Bioanal. Chem. 2019, 411, 6767-6775. [CrossRef]

31. Kim, Y.S.; Katase, T.; Horii, Y.; Yamashita, N.; Makino, M.; Uchiyama, T.; Fujimoto, Y.; Inou, T. Estrogen equivalent concentration of individual isomer-specific 4-nonylphenol in Ariake sea water, Japan. Mar. Pollut. Bull. 2005, 51, 850-856. [CrossRef]

32. Lu, Z.J.; Gan, J. Analysis, toxicity, occurrence and biodegradation of nonylphenol isomers: A review. Environ. Int. 2014, 73, 334-345. [CrossRef] [PubMed]

33. Pollard, A.T.; Morra, M.J. Estrogens: Properties, behaviors, and fate in dairy manure-amended soils. Environ. Rev. 2017, 25, 452-462. [CrossRef]

34. Bautista-Toledo, I.; Ferro-Garcia, M.A.; Rivera-Utrilla, J.; Moreno-Castilla, C.; Vegas Fernandez, F.J. Bisphenol A removal from water by activated carbon. Effect of carbon characteristics and solution chemistry. Environ. Sci. Technol. 2005, 39, 6246-6250. [PubMed]

35. Stumpe, B.; Marschner, B. Dissolved organic carbon from sewage sludge and manure can affect estrogen sorption and mineralization in soils. Environ. Pollut. 2010, 158, 148-154. [CrossRef]

36. Yang, G.P.; Ding, H.Y.; Cao, X.Y.; Ding, Q.Y. Sorption behavior of nonylphenol on marine sediments: Effect of temperature, medium, sediment organic carbon and surfactant. Mar. Pollut. Bull. 2011, 62, 2362-2369. [CrossRef]

37. Soni, H.; Padmaja, P. Palm shell based activated carbon for removal of bisphenol A: An equilibrium, kinetic and thermodynamic study. J. Porous Mater. 2014, 21, 275-284. [CrossRef]

38. Wang, L.; Zhao, J.M.; Li, Y.M. Removal of bisphenol A and 4-n-nonylphenol coupled to nitrate reduction using acclimated activated sludge under anaerobic conditions. J. Chem. Technol. Biot. 2014, 89, 391-400. [CrossRef]

39. Ding, J.; Cheng, Y.; Hua, Z.L.; Yuan, C.; Wang, X.J. The Effect of dissolved organic matter (DOM) on the release and distribution of endocrine-disrupting chemicals (EDCs) from sediment under hydrodynamic forces, A Case Study of Bisphenol A (BPA) and Nonylphenol (NP). Int. J. Environ. Res. Public Health 2019, 16, 1724. [CrossRef] [PubMed]

40. Wang, B.; Zeng, D.; Chen, Y.; Belzile, N.; Bai, Y.; Zhu, J. Adsorption behaviors of phenanthrene and bisphenol A in purple paddy soils amended with straw-derived DOM in the West Sichuan Plain of China. Ecotoxicol. Environ. Saf. 2019, 169, 737-746. [CrossRef] [PubMed]

41. Wu, W.Y.; Liu, H.L.; Chen, H.H.; Hao, Z.Y.; Shi, Y.B.; Ma, F.S. Effect of regulation and storage engineering on groundwater salinity in reclaimed water irrigation district. Trans. CSAE 2009, 25, 22-25.

42. Bao, Z. Research on Pollution Risk of Heavy Metals in Soil and Groundwater under Reclaimed Water Irrigation; China University of Geosciences: Beijing, China, 2014.

43. USEPA. SW-846 Test Method 3550C: Ultrasonic Extraction. Available online: https://www.epa.gov/hw-sw846/sw-846-testmethod-3550c-ultrasonic-extraction (accessed on 13 September 2021).

44. Düring, R.A.; Krahe, S.; Gäth, S. Sorption behavior of nonylphenol in terrestrial soils. Environ. Sci. Technol. 2002, 36, 4052-4057. [CrossRef] [PubMed]

45. Murillo-Torres, R.; Durán-Álvarez, J.C.; Prado, B.; Jiménez-Cisneros, B.E. Sorption and mobility of two micropollutants in three agricultural soils: A comparative analysis of their behavior in batch and column experiments. Geoderma 2012, 189-190, 462-468. [CrossRef]

46. Martz, M.; Heil, J.; Marschner, B.; Stumpe, B. Effects of soil organic carbon (SOC) content and accessibility in subsoils on the sorption processes of the model pollutants nonylphenol (4-n-NP) and perfluorooctanoic acid (PFOA). Sci. Total Environ. 2019, 672, 162-173. [CrossRef]

47. Francis, C.A.; Roberts, K.J.; Beman, J.M.; Santoro, A.E.; Oakley, B.B. Ubiquity and diversity of ammonia-oxidizing archaea in water columns and sediments of the ocean. Proc. Natl. Acad. Sci. USA 2005, 102, 14683. [CrossRef] [PubMed]

48. Jiang, L.; Wang, J.H.; Li, J.Z.; Xin, J.; Li, M.; Liu, X. Sorption and desorption of $17 \alpha$-ethinyl estradiol and 4-n-nonylphenol in Soil. Environ. Sci. 2012, 33, 3885-3892.

49. Tang, X.Y.; Zhou, Y.B.; Li, X.S.; Xu, Y.X.; Zhao, Q.; Lu, J. Sorption of bisphenol A from aqueous solution by modified fabric peat. Environ. Sci. Technol. 2011, 34, 53-58.

50. Tong, X.; Li, Y.X.; Zhang, F.S.; Chen, X.C.; Zhao, Y.; Hu, B.Y.; Zhang, X.L. Adsorption of 17 $\beta$-estradiol onto humic-mineral complexes and effects of temperature, $\mathrm{pH}$, and bisphenol A on the adsorption process. Environ. Pollut. 2019, $254,112924$. [CrossRef] [PubMed]

51. Sun, K.; Jin, J.; Gao, B.; Zhang, Z.; Wang, Z.; Pan, Z.; Xu, D.; Zhao, Y. Sorption of $17 \alpha$-ethinyl estradiol, bisphenol A and phenanthrene to different size fractions of soil and sediment. Chemosphere 2012, 88, 577-583. [CrossRef] [PubMed]

52. Karickho, S.W. Semi-empirical estimation of sorption of hydrophobic pollutants on natural sediments and soils. Chemosphere 1981, 10, 833-846. [CrossRef]

53. Zhu, D.; Hyun, S.; Pignatello, J.J.; Lee, L.S. Evidence for П-П electron donor acceptor interactions between-donor aromatic compounds and $\Pi$-acceptor sites in soil organic matter through pH effects on sorption. Environ. Sci. Technol. 2004, 38, 4361-4368. [CrossRef]

54. Ma, L.; Yates, S.R. Dissolved organic matter and estrogen interactions regulate estrogen removal in the aqueous environment: A review. Sci. Total Environ. 2018, 641, 529-542. [CrossRef] [PubMed] 
55. Ren, D.; Huang, B.; Yang, B.Q.; Pan, X.J.; Dionysiou, D.D. Mitigating $17 \alpha$-ethynylestradiol water contamination through binding and photosensitization by dissolved humic substances. J. Hazard. Mater. 2017, 327, 197-205. [CrossRef]

56. Wang, Y.P.; Yang, Z.L.; Li, Z.; Ren, H.J. Degradation and Sorption of Nonylphenol in Soils. J. Agro-Environ. Sci. 2011, 30, 1561-1566.

57. Milinovic, J.; Lacorte, S.; Rigol, A.; Vidal, M. Sorption behaviour of nonylphenol and nonylphenol monoethoxylate in soils. Chemosphere 2015, 138, 952-959. [CrossRef]

58. Isobe, T.; Nishiyama, H.; Nakashima, A. Distribution and behavior of nonylphenol, octylphenol and nonylphenol monoethoxylate in Tokyo metropolitan area: Their association with aquatic particles and sedimentary distributions. Environ. Sci. Technol. 2001, 35, 1041-1049. [CrossRef]

59. Hou, S.G.; Sun, H.W.; Gao, Y. Sorption of small metabolites of nonylphenol polyethoxylates in single and complex systems on aquatic suspended particulate matter. Chemosphere 2006, 63, 31-38. [CrossRef]

60. Navarro, A.; Endo, S.; Gocht, T.; Barth, J.A.C.; Lacorte, S.; Barceló, D. Sorption of alkylphenols on Ebro River sediments: Comparing isotherms with field observations in river water and sediments. Environ. Pollut. 2009, 157, 698-703. [CrossRef]

61. Li, C.; Ji, R.; Schäffer, A.; Sequaris, J.M.; Amelung, W.; Vereecken, H.; Klumpp, E. Sorption of a branched nonylphenol and perfluorooctanoic acid on Yangtze River sediments and their model components. J. Environ. Monitor. 2012, 14, $2653-2658$. [CrossRef] [PubMed]

62. Collins, C.D.; Martin, I.; Doucette, W. Organic Xenobiotics and Plants: From mode of action to Ecophysiology. In Plant Uptake of Xenobiotics; Schroder, P., Collins, C.D., Eds.; Springer: Heidelberg, Germany, 2011; pp. 3-16.

63. Sadmani, A.H.M.A.; Andrews, R.C.; Bagley, D.M. Nanofiltration of pharmaceutically active and endocrine disrupting compounds as a function of compound interactions with DOM fractions and cations in natural water. Sep. Purif. Technol. 2014, 122, 462-471. [CrossRef]

64. Sadmani, A.H.M.A.; Andrews, R.C.; Bagley, D.M. Rejection of pharmaceutically active and endocrine disrupting compounds by nanofiltration as a function of source water humic substances. J. Water. Process. Eng. 2014, 2, 63-70. [CrossRef]

65. Chen, W.; Pan, S.; Cheng, H.; Sweetman, A.J.; Zhang, H.; Jones, K.C. Diffusive gradients in thin-films (DGT) for in situ sampling of selected endocrine disrupting chemicals (EDCs) in waters. Water Res. 2018, 137, 211-219. [CrossRef]

66. Shchegolikhina, A.; Mouvenchery, Y.K.; Woche, S.K.; Bachmann, J.; Schaumann, G.E.; Marschner, B. Cation treatment and drying-temperature effects on nonylphenol and phenanthrene sorption to a sandy soil. J. Plant Nutr. Soil Sci. 2014, 177, 141-149. [CrossRef]

67. Lu, J.H.; Wu, L.; Letey, J. Effects of soil and water properties on anionic polyacrylamide sorption. Soil Sci. Soc. Am. J. 2002, 66, 578-584. [CrossRef]

68. Schnitzer, M.; Scinner, S. Organo-metallic interactions in soil.4. Carboxyl and hydroxyl groups in organic matter and metal retention. Soil Sci. 1965, 99, 278-284.

69. Kunhi Mouvenchery, Y.; Kuèerík, J.; Diehl, D.; Schaumann, G.E. Cation-mediated cross-linking in natural organic matter: A review. Rev. Environ. Sci. Biotechnol. 2012, 11, 41-54. [CrossRef]

70. Lu, Y.F.; Pignatello, J.J. Sorption of apolar aromatic compounds to soil humic acid particles affected by aluminum (III) ion cross-linking. J. Environ. Qual. 2004, 33, 1314-1321. [CrossRef] [PubMed]

71. Varadachari, C.; Chattopadhyay, T.; Ghosh, K. Complexation of humic substances with oxides of iron and aluminium. Soil Sci. 1997, 162, 28-34. [CrossRef]

72. Jackson, M.; Sowa, M.G.; Mantsch, H.H. Infrared spectroscopy: A new frontier in medicine. Biophys. Chem. 1997, 68, 109. [CrossRef]

73. Melin, A.; Perromat, A.; Deleris, G. Pharmacologic application of Fourier transform IR spectroscopy: In vivo toxicity of carbon tetrachloride on rat liver. Biopolym. (Biospectroscopy) 2000, 57, 160. [CrossRef]

74. Severcan, F.; Sahin, I.; Kazanci, N. Melatonin strongly interacts with zwitterionic model membranes-evidence from Fourier transform infrared spectroscopy and differential scanning calorimetry. Biochim. Biophys. Acta 2005, 1668, 215. [CrossRef]

75. Jiang, L. The Behavior of $17 \alpha$-Ethinyl Estradiol and 4-n-nonylphenol in Soil by Groundwater Recharge with Reclaimed Water; Tsinghua University: Beijing, China, 2012. 